\title{
Ossos de borboleta sob um céu-e(c)plise: nas dobras em órgãos da coleção de panapaná em Régis Bonvicino"
}

\author{
Fernando Floriani Petry
}

\begin{abstract}
Resumo: Este artıgo procura manobrar as operaçōes acerca dos mundos de sentıdos artıculadas em Jean-Luc Nancy - El sentido del mundo - com as considerações de Gilles Deleuze e Félix Guattari sobre Como criar para si um corpo sem órgãos. Partindo desses filósofos franceses, objetivamos estabelecer as correspondências entre sentido, verdade e deserto por meio das experimentações poéticas de Régis Bonvicino, principalmente em alguns poemas dos livros Ossos de borboleta, Céu-eclipse, Remorso do cosmos e Página órfã, a fim de articular a proposta de uma política máxima da vida. Questionando o que adotamos por sentido natural ou verdade, o percurso deste trabalho é pelos caminhos triviais a que a poesia trivial de Bonvicino nos incita, lendo, por meio das imagens de ossos de borboleta, borboflores, florbelhas, flormigas, na imagem do panapaná - a coleção de borboletas - a possibilidade de adotarmos a atitude de criarmos para nós mesmos um corpo sem órgãos.

Palavras-chave. Corpo sem órgãos; Sentido; Verdade; Taxidermia; Poesia de Régis Bonvicino.

Abstract. This article attempts to handle the operations on the worlds of meaning articulated by Jean-Luc Nancy in The sense of the world - with considerations of Gilles Deleuze and Félix Guattari on How to create a body without organs. Based on these French philosophers the article aimed to establish the connections between meaning, truth and desert through the poetic experiences of Régis Bonvicino, especially in some poems from books Butterfly Bones, Sky-Eclipse, the Cosmos and remorse, and Orphan page to articulate the proposal of a maximum life policy. Questioning the meaning adopted by natural meaning or truth, the goal of this paper is go through the images of bones of butterfly, borboflores, florbelhas, flormigas, the image of panapaná - a collection of butterflies - seeking the possibility of adopting the attitude of creating for ourselves a Body without Organs. Keywords. Body without organs; Meaning; Truth; Taxidermy; Régis Bonvicino poetry.
\end{abstract}

Yo sé de un laberinto griego que es una línea única, recta. En esa línea se han perdido tantos filósofos..

Jorge Luis Borges

Partindo das operações de Jean-Luc Nancy, em seu livro El sentido del mundo, dos conceitos de sentido, mundo e deserto apresentados pelo autor, tentaremos, neste artigo, corresponder às noções de corpo sem órgãos,

\footnotetext{
"O presente artigo é uma compilação do trabalho de conclusão de curso em letras-português, habilitação bacharelado, pela Universidade Federal de Santa Catarina, defendido no início de 2009, nas dependências do Núcleo de Estudos Literários e Culturais (NELIC), sob orientação da professora doutora Maria Lucia de Barros Camargo.

Mestrando pelo Programa de Pós Graduação em Literatura da Universidade Federal de Santa Catarina. E-mail: ferpetry@terra.com.br
} 
de Gilles Deleuze e Félix Guattari em Mil platôs, a fim de desenvolver o que chamamos de política máxima de vida. O objetivo deste trabalho é compreender como os conceitos de sentido elaborados por Nancy podem operar por meio da proposta de exercício, de experimentação poética em Régis Bonvicino, adotando a perspectiva de que a poesia de Bonvicino pode ser orientada pela tentativa de criar para si um corpo sem órgãos.

Questionando o que rotulamos como sentido natural, tentaremos percorrer os vários caminhos que a poesia trivial de Bonvicino nos sugere. Trivial não por ser do conhecimento de todos, mas por ser trivium, um caminho que se bifurca em um, dois, três e tantos mais outros mesmos caminhos. Trivial por ler as imagens muito batidas, corriqueiras que o poeta desertifica, esvazia de seu sentido natural, bifurcando-as em novos e outros oásis, por meio de seu próprio trivium, (des)organizando a gramática, invertendo a lógica e abusando de sua retórica para (re)criar imagens de ossos de borboleta, de páginas órfãs, de "borboflores, florbelhas, flormigas, borr" (ANTELO, 1996, p. 143) e outros tantos seres sem órgãos.

Portanto, este texto começa em seu começo, desenvolve-se em seu meio e toma a única liberdade de não terminar, de nada concluir, pois seu intento é ser processo, movimento, uma guerra de intensidades, constantemente partir. Partir do trivial, percorrer o trivium, caçando ossos de borboletas.

\section{Percorrendo desertos de sentido}

Jean-Luc Nancy começa seu livro El sentido del mundo afirmando que há bem pouco tempo se podia falar de uma crise de sentido. E que uma crise, por sua natureza, analisa-se e se supera-se. Se atravessássemos uma crise de sentido, já teria surgido, em algum dos confins do mundo, a possibilidade de reencontrarmos o sentido, de retornarmos ao único caminho certo. Contudo, não atravessamos mais uma crise de

\footnotetext{
${ }^{1}$ De acordo com o dicionário Houaiss, trivium, na Idade Média, era a primeira parte do ensino universitário, formada por três disciplinas (gramática latina, lógica e retórica) ministradas antes do quadrivium e que, com este último, constituía as sete artes ou as artes liberais. 
sentido - ou da ausência de sentido -, mas sim estamos, hoje, ainda mais distantes: "todo el sentido se encuentra en estado de abandono" (NANCY, 2003, p. 14).

Os sentimentos despertados pelo estado de abandono do sentido, em nosso tempo, são paradoxais. Por um lado, a demanda de sentido produz manifestações tais como "esa banderola en Berlín, sobre un teatro, en 1993, Wir brauchen Leitbilder: tenemos necesidad de imágenes directrices" (NANCY, 2003, p. 14). Anecessidade de imagens diretrizes é a querença do retorno do sentido-verdade, com sua segurança, identidade, certeza. Por outro lado, é despertado em alguns o sentimento de que temos todas as chances de superar a necessidade de imagens diretrizes, em um sentido inédito que precede todos os outros, surpreendentemente. Um sentido que vai para além da verdade. Para alguns, temos uma excelente oportunidade para sairmos ao deserto.

Agora, como atingirmos um sentido que precede todos os outros sentidos? Como compreender o sentido dessa sentença? Antes de qualquer coisa, é preciso estabelecer as definições que servirão de base para o desenvolvimento das ideias fundamentais de Nancy acerca do fim do mundo dos sentidos. O movimento inicial é diferenciar o que aqui chamamos de sentido natural do que entendemos por sentido. Portanto, primeiramente precisamos estabelecer a relação que Nancy desenvolve entre as coisas e o mundo:

[...] así, "ser en el mundo", si tal cosa tiene lugar (pero tal cosa tiene lugar) está tomado en el sentido que antecede toda significación. Tal cosa hace sentido, demanda o propone sentido más acá o más allá de toda significación. Si nosotros estamos en el mundo, si hay ser-en-el-mundo en general, es decir, si hay mundo, entonces hay sentido. [...] Así, mundo no sólo es correlativo de sentido, está estructurado como sentido, y recíprocamente, sentido está estructurado como mundo. En definitiva "el sentido del mundo" es una expresión tautológica. (NANCY, 2003, p. 22)

Notamos, aqui, a separação entre sentido e significação: uma coisa tem, necessariamente, sentido e uma pequena parcela desse sentido é sua significação. Só há coisa se há sentido. Contudo, nem todas as coisas possuem 
significação. Ou melhor, se uma coisa tem lugar, tem lugar neste mundo, ela tem um sentido que precede toda significação. E o que tal coisa significa é apenas um dos sentidos que essa coisa pode ter. Em outros termos, o sentido é deserto; a significação, oásis. O deserto continua a existir se lhe for subtraído o oásis; porém, é parte integrante do oásis o deserto.

Assim sendo, das duas posturas anteriormente destacadas em Nancy, hastear a bandeirola berlinense é adotar o oásis como moradia e abrigo. Como verdade. Seguir um sentido que precede toda a significação é adentrar ao deserto. Em outros termos, hastear a demanda de sentido é impor a necessidade de interpretar o mundo. E a nós, beduínos, cabe a possibilidade de transformá-lo, correspondê-lo:

[...] ya no se trata de prestarle o de darle un sentido más, sino de entrar en ese sentido, [...] transformar debe querer decir "cambiar el sentido del sentido", pasar del tener al ser, por decirlo así todavía una vez más. Lo cual quiere decir también que la transformación es una praxis, no una poiesis; una acción que efectúa el agente, no la obra. (NANCY, 2003, p. 23)

Já não se trata de atribuir uma significação, uma verdade. Trata-se de atravessar o deserto dos sentidos, em uma práxis, ${ }^{2}$ em uma atitude diante do mundo, diante do oásis.

2. De significação (significado), sentido e verdade.

Convém, antes de adentrarmos o deserto do corpo, sabermos reconhecer o trivial caminho que pretendemos percorrer. Assim, é preciso estabelecer

\footnotetext{
${ }^{2}$ Não cabe, nesse atual percurso, aprofundarmos as discussões acerca de práxis. Porém, por ter uma ligação muito forte com as teorias marxistas, também não é seguro adotar o termo sem alguma colocação, mesmo que Nancy também não o referencie. Adolfo Sánchez Vázquez a define como "atividade material do homem que transforma o mundo natural e social para fazer dele um mundo humano" (SÁNCHEZ VÁZQUEZ, 1977, p. 3). E continua, "Praxis, em grego antigo, significa ação para levar a cabo algo, mas uma ação que tem seu fim em si mesma e que não cria ou produz um objeto alheio ao agente ou a sua atividade. Nesse sentido, a ação moral - da mesma maneira que qualquer tipo de ação, que não engendre nada fora de si mesma - é, como diz Aristóteles, práxis; pela mesma razão, a atividade do artesão que produz algo que chega a existir fora do agente de seus atos não é práxis. A esse tipo de ação que cria um objeto exterior ao sujeito e a seus atos se chama [...] poiésis, que significa literalmente produção ou fabricação." (SÁNCHEZ VÁZQUEZ, 1977, p. 4-5) Praxis, aqui, entenderemos como atividade, atitude, ação que efetua o agente. Uma atividade moral do agente diante do mundo-verdade, diante do oásis. 
os sentidos de significação e, portanto, significado; além dos sentidos do próprio sentido e de verdade, para somente então atingirmos o passo inicial, a diferenciação entre sentido e sentido natural, doravante, verdade.

Significação, em português, remete diretamente a significado. Aquele, segundo o dicionário Houaiss, pode ser definido como importância, valor, como conteúdo semântico de um signo linguístico, conceito, sentido. Porém, como vimos em Nancy, significado diz respeito somente a um aspecto do sentido, ou melhor, é a valoração de um sentido dentre todos os sentidos possíveis. O sentido é o infinito das ocorrências de sentido - incluindo, portanto, as ocorrências absurdas e inimagináveis. O significado é a moralização, a valoração ${ }^{3}$ desse universo de sentidos.

Assim se constrói uma verdade. Verdadeiro é o significado que melhor interpreta a moral, os valores sociais, religiosos, políticos, culturais. A verdade tem por função apresentar um fim, impor limites e fronteiras ao deserto do sentido. Tem por função ser não um sentido qualquer, ou um significado apenas, e sim ser O significado, O único sentido, pondo fim ao deserto, construindo muralhas no oásis. Seja para preservar os valores do capitalismo, da religião, do princípio familiar, da vergonha e do pudor, seja para impor a vontade de alguns sobre muitos; a verdade opera a significação de maneira a findá-la, congelá-la ou, como veremos adiante, empalhá-la.

Adentramos agora em uma delicada situação, paradoxal. Se digo sentido é..., ou o sentido é..., acabamos por realizar a mesma operação que aqui tentamos desconstruir. É preciso conceituar os termos que utilizamos com o cuidado de não construirmos verdades! Mas como? Para nos responder, Nancy recorre a Derrida:

[...] "ni palabra, ni concepto", escribe Derrida acerca de la diferencia.

\footnotetext{
${ }^{3}$ Seja pela Igreja Católica, seja pelo capitalismo, seja pela cultura. São também infindáveis os mecanismos de valoração e interpretação do sentido.

${ }^{4}$ Se pensarmos nas verdades religiosas, a verdade é Deus. Porém, a verdade é finita, e Deus, empalhado. Deus está morto, por ser verdade: "El ser-essentia, que tiene su fin en sí mismo - y que en este sentido está finalizado, acabado, rematado y perfecto, infinitamente perfecto -, es a lo sumo pura verdad, pero verdad privada de sentido: y es exactamente por esto que Dios, en tanto que un tal ser, está muerto." (NANCY, 2003, p. 58)

5 Nota do autor: "La différance", en Marges de la Philosophie, Paris, Minuit, 1972, p. 5. Recordemos al menos este pasaje del texto: "la diferancia es lo que hace que el movimiento de la significación no sea posible más que si cada elemento dice 'presente', apareciendo sobre la escena de la presencia, remitiéndose a otra cosa que él mismo, guardando en él la marca del elemento pasado y dejándose ya 
A fin de cuentas, se trata de la definición del sentido, mejor aún, del sentido del sentido, de no ser ni palabra ni concepto, ni significante, ni significado, sino envío y desvío, y sin embargo, y por esto mismo, gesto de escritura, apertura y forzamiento de un ha cuya significación y destinación completas (la à del $h a$ ) consiste en excribirse: en ir a tocar lo concreto del mundo allí donde la existencia hace sentido. (NANCY, 2003, p. 32)

Nem palavra, nem conceito. Deserto. Possibilidade de ir e vir, gesto, movimento, atravessamento. Para não construirmos verdades sobre o que é o sentido, devemos tocar o mundo onde o sentido existe. Portanto, para escaparmos da verdade, devemos tentar não valorar o percurso que aqui propomos. Não deve ser belo, horrendo, agradável, ou absurdamente desviante. Devemos percorrê-lo, apenas percorrê-lo, para um além de. Atentos como quem atravessa um deserto.

Separados o sentido da verdade, adotar a práxis de desconstruir, (dês) organizar a demanda de sentido é encarar o mundo de maneira fascinantemente indiferente. É poder dizer que o mundo é trivial. Simples. De uma complexa simplicidade.

Encarnar a práxis de acarar o mundo como deserto, esvaziando-o de suas verdades-oásis por meio da trivialidade é a atitude que podemos ler nas poesias de Régis Bonvicino. Raul Antelo, ao final de Ossos de borboleta, nos lembra que o título do livro, dentre tantas figuras triviais, é um tropismo animal. A borboleta ganha ossos ao atirar-se ao deserto, desde a epígrafe escolhida por Régis para seu livro, "The world is all that is displaced", de Michael Palmer, passando pelo Ego de um Homem sem sombra (Ego), pela quieta e vasta/ a flor ignora/ o dia/ que passa $(\mathrm{Na})$, até atingir a folha que cai (Sem título (4)). Desertificando as verdades próprias, "é o limo do nada ou o miasma do mesmo. Para Bonvicino, 'a poesia / forma em linha com o nada' e sua confidência, portanto, não admite heranças doces" (ANTELO, 1996, p. 144). Ni palabra, ni concepto, Ossos de Borboleta é movimento, é a práxis de por-se em constante atravessar.

ahondar por la marca de su relación con el elemento futuro [...]. Es necesario que un intervalo lo separe de lo que no es él para que se él-mismo, pero este intervalo que lo constituye en presente también debe divisar a la vez el presente en sí mismo [...] (p. 13).” En los términos de este pasaje, la distinción que hago entre la verdad y el sentido es la distinción entre la presentación de un presente sobre la escena de la presencia, y su división en si-mismo. 
As imagens triviais que Bonvicino, retoricamente, explora com sua lógica invertida são, por nós, explicadas ao retomarmos Nancy, uma vez que o filósofo francês afirma que

[...] el vocablo mundo no tiene otra unidad de sentido que ésta: un mundo (el mundo, mi mundo, el mundo de los negocios, el mundo musulmán etc.) es siempre una articulación diferencial de singularidades que hacen sentido articulándose en su mismísima articulación (donde articulación debe tornarse a la vez en sentido mecánico, de unión y de juego, en el sentido de la proliferación parlante y en el sentido de la distribución en artículos distintos). Un mundo ensamblado, jugado, hablado y compartido: he aquí su sentido, que no es otro que el sentido de 'hacer sentido'. [...] Se podría decir: el sentido es coextensivo a los confines del mundo, 'no va más lejos' - pero eso sucedería con la condición de añadir inmediatamente: el mundo se extiende hasta las extremidades del sentido, absolutamente. (NANCY, 2003, p. 124)

As articulações entre ossos e borboleta, entre céu e eclipse, entre o homem e a sua sem sombra correspondem - e não interpretam - sentidos diversos, singularidades esticando as extremidades de cada um dos oásis, fazendo-os tocarem-se em pleno deserto. Percorrendo os caminhos do trivium. Em forma com o nada, a poesia de Régis expande o limiar entre o oásis e o deserto. Invertendo a lógica de verdade das coisas, a atitude que a poesia de Bonvicino requer do leitor é justamente a de não hastear as bandeirolas, é sim a atitude de tocar(-se) e ser tocado pela poesia, transformando(-se) em outros, em si-mesmo, em um constante ir e vir entre o oásis e o deserto.

Não é sem apelo que Bonvicino confessa:

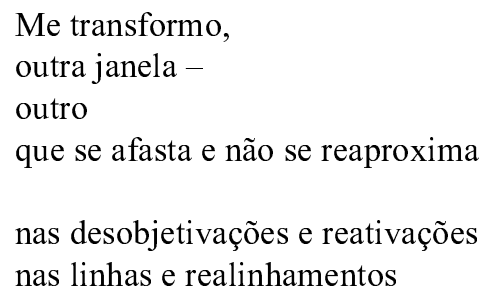

\footnotetext{
${ }^{6}$ Por lógica invertida entendemos as operações que Régis Bonvicino realiza, em sua poética, invertendo o sentido lógico, verdadeiro, das imagens exploradas. Logicamente, é impossível que uma borboleta tenha ossos. Não faz parte do mundo-verdade, mundo-natural, uma borboleta com ossos. 
outros

me atravessam

morto de ser

coisas perdem sentido

expressões figuradas como

ossos de borboleta

me transformo

na observação

de uma pétala

Me destransformo

a mesma janela -

outro

que não se afasta

nas objetivações,

alinhamentos

e linhas inexistentes

iguais me repassam

Retrato desativado,

Taxidermista de mim mesmo (BONVICINO, 1996, p. 13-14),

pois é na transformação de si mesmo em si mesmo que se abre a possibilidade de atravessarmos o deserto, com algo que se afasta e não se reaproxima, desconstruindo as verdades-oásis com desobjetivações e reativações de outros novos velhos sentidos. É na observação da trivialidade que se percorre o deserto. Em cima de uma pétala.

E o poeta retorna ao oásis, destransforma-se, objetiva-se, valoriza-se, interrompe o toque e retoma o retrato ${ }^{8}$ desativado. $\mathrm{O}$ retrato do taxidermista.

\footnotetext{
${ }^{7}$ Nota-se a ambivalência proposta por Bonvicino ao criar a imagem do taxidermista de si mesmo. Ao mesmo tempo agente, práxis; e passivo, poiésis. Ao mesmo tempo em que realiza uma atividade moral, ele a faz fora de si, por meio da obra, desativando o próprio retrato.

${ }^{8}$ Vale lembrar que Nancy põe fim às dúvidas quanto ao encerramento ou não do ciclo da representação: "No es una casualidad que hoy el teatro ya no posea nuevas fábulas, nuevos müthos [sic], una vez agotada la fábula total (Wagner o Claudel), la fábula moderna (Brecht), la fábula del fin de las fábulas (Beckett). El telón ha caído sobre la escena metafísica, sobre la metafísica como escena de la (re)presentación." (NANCY, 2003, p. 46) 


\section{Transformações em um corpo deserto}

Já vimos como Bonvicino recria seu trivium, invertendo a lógica da verdade, articulando de maneiras diversas os diversos sentidos da gramática, entre prefixos, sufixos e desmembramentos de palavras. Da retórica do poeta nos sobra apenas uma Página órfã.

João Adolfo Hansen nos aponta, em seu "A palavra-carcaça de Bonvicino" (2007), que os poemas do autor são compostos por justaposições integradoras de pedaços de sentidos absurdos. Não são fragmentos. Não se propõe um rasgo. Os poemas são compostos por diferentes articulações de diversos sentidos. Corpos que atravessam, órfãos, o deserto. São corpos vazios, indefinidos que rasgam(-se) deserto afora.

Em Página órfã, aparecem as duas possibilidades percebidas por Nancy diante do abandono do sentido. Há, por um lado, o corpo indefinido, ninguém, sem nome, o corpo do mendigo, carcaça, que morre a pauladas ("Rascunho") - de onde se pressupõe que estava vivo -; e, por outro lado, o corpo docilmente siliconado, corpo modelo, verdade, de alguém que não sabe escrever o próprio nome - de onde se pressupõe que o tem ("Roupoema").

Dos corpos que transitam pela obra de Bonvicino, temos o corpo movimento, o corpo vivo, apto a atravessar o deserto, e o corpo cadavérico, analfabeto, taxidérmico de uma modelo: "Seus dentes poderiam fazer merchandising/ de maconha/ embora façam de Colgate/ dos lóbulos caem pingentes// to sell ou vender/ seus pés não pisam em piso falso/ e andam descalços/ num clipe ou num filme// [...] não vende roupa/ vende os lábios/ os lábios vendem a boca,/ cornucópia de si mesma// ouve tecno e hip-hop/ digita no papelote/ não sabe escrever nada/ além do próprio nome".

O corpo de uma modelo aparece, sob a régia conduta de seus órgãos, como imagem da verdade social estipulada, por meio da moda, do capital - to sell - e da preservação da pele, dos cheiros dos cosméticos. Bonvicino declara guerra ao modelo, em Página órfã.

Porém, se retornarmos a 28 de novembro de 1947, recordaremos que Antonin Artaud declara guerra aos órgãos, "porque atem-me se quiserem, mas nada há de mais inútil do que um órgão" (apud DELEUZE; GUATTARI, 1996, p. 9). Porque nada há de mais inútil que um organismo natural. Nada há de mais inútil que to sell sandálias pretas, os lábios ou cocaína. Nada há de mais inútil que fazer blowjob para preservar os cheiros dos cosméticos no clitóris. 
Por meio de sua poética em Página órfã, Bonvicino nos apresenta a possibilidade de queimarmos em praça pública a bandeirola berlinense de 1993 somente com nosso corpo. Isso porque queimar bandeiras e verdades é um exercício, uma experimentação, é ter corpo para atravessar o deserto. Uma práxis.

Podemos ter o corpo taxidérmico que se destransforma em um retrato desativado, morto, que aguenta as verdades, sobrevive vendendo seus sorrisos à Colgate; ou podemos adotar a atitude - e, novamente, a práxis - de experimentar a possibilidade da travessia, podemos nos transformar em órfãos de órgãos e termos um verdadeiro panapaná - coletivo de borboletas - em nossos ossos.

Porém, a guerra declarada por Artaud ou por Bonvicino não é contra os corpos em si mesmos. As batalhas de Antonin e as ferrenhas criticas de Régis são contra os órgãos, contra as organizações orgânicas dos órgãos. Para nos direcionar melhor nesses percursos triviais pelos órgãos de um corpo sem órgãos, Deleuze e Guattari, em seu ensaio "Como criar para si um corpo sem órgãos", lembram-nos que o corpo sem órgãos pode ser compreendido como um exercício. Uma experiência inevitável. É sobre o corpo sem órgãos que experimentamos a biologia, a política, a censura, a vida e seu esgotamento. Se atentarmos ao poema Me transformo, de Bonvicino, o corpo que se alinha, objetivando-se em iguais verdades orgânicas, está repleto de seus órgãos, contaminado pela demanda de ordem orgânica por seu próprio organismo, uma vez que o sentido natural do organismo pressupõe ordem.

Já o CsO, proposto por Deleuze e Guattari é uma prática - práxis -, uma lição de partir para longe do oásis. Porém, justamente por ser uma prática, uma atitude, "ao corpo sem órgãos não se chega, não se pode chegar, nunca se acaba de chegar a ele, é um limite" (DELEUZE; GUATTARI, 1996, p. 10), não se esgota. É com e sobre ele que vivemos, morremos, dormimos, comemos, partimos, é ele que vencemos e somos vencidos. O CsO é a experiência vida. Ou melhor, é o mundo dos sentidos da palavra vida.

Dentre todos os corpos, o corpo hipocondríaco (de órgãos destruídos, com o qual nada mais acontece), o corpo paranóico (cujos órgãos não se cansam de serem atacados e renovados exteriormente, o corpo que se regenera para ser novamente destruído), o corpo esquizo (catatônico, em constante embate, em constante divisão, sempre consigo), o corpo drogado de uma modelo (um esquizo externo), o corpo masoquista (da suspensão do corpo para o interromper do exercício dos órgãos, por meio da dor), dentre todos esses fantasmas, Deleuze e Guattari questionam: 
Ossos de borboleta sob um céu-eclipse - nas obras sem orgãos da coleção de panapaná ...

[...] por que estes exemplos? Por que é necessário passar por eles? Corpos esvaziados em lugar de plenos. Que aconteceu? Você agiu com a prudência necessária? Não digo sabedoria, mas prudência como dose, como regra imanente à experimentação: injeções de prudência. Muitos são os derrotados nesta batalha. Será tão triste e perigoso não mais suportar os olhos para ver, os pulmões para respirar, a boca para engolir, a língua para falar, o cérebro para pensar, o ânus e a laringe, a cabeça e as pernas? Por que não caminhar com a cabeça, cantar com o sinus, ver com a pele, respirar com o ventre, Coisa simples, Entidade, Corpo pleno, Viagem imóvel, Anorexia, Visão cutânea, Yoga, Krishna, Love, Experimentação. Onde a psicanálise diz: Pare, reencontre o seu eu, seria preciso dizer: vamos mais longe, não encontramos ainda nosso $\mathrm{CsO}$, não desfizemos ainda suficientemente nosso eu. Substituir a anamnese pelo esquecimento, a interpretação pela experimentação. Encontre seu corpo sem órgãos, saiba fazê-lo, é uma questão de vida ou de morte, de juventude e de velhice, de tristeza e de alegria. É aí que tudo se decide. (DELEUZE; GUATTARI, 1996, p. 11)

A política da psicanálise, de acordo com Deleuze e Guattari, proporia um retorno ao eu, enquanto o que chamamos de política máxima da vida afirma ser necessário ir mais além, desfazer-se ainda mais, dividir-se ainda mais. Seria preciso esquecer-se da interpretação e iniciar-se a experimentação, a práxis de transformar o mundo, percorrer todo o deserto dos sentidos. Inclusive porque mesmo em tempos não ditatoriais, nos quais os extremos não são as únicas opções, o CsO continua sendo uma política que define uma questão entre vida e morte. Ou melhor, entre vida, sobrevida e morte. Afinal, o CsO é o movimento de percepção do que resta quando tudo foi retirado. Seria a possibilidade de viver quando esgotar-se toda a água do oásis.

Porém, o CsO não é um manual de taxidermia; afinal, enquanto a taxidermia nos mostra e nos ensina o que retirar, ensina-nos o retrato, o $\mathrm{CsO}$ nos faz ver o que foi retirado, o que sobra da experimentação, da transformação. Ou melhor, a taxidermia empalha o corpo, para garanti-lo nos oásis da verdade imutável, dogmática. Já o CsO é a possibilidade de ir para além de, atravessar o deserto, libertar-se da prisão de sentidos de Deus.

A taxidermia é definida como um antigo processo de encher de palha um animal morto a fim de conservar-lhe as características. Porém, conservar-lhe

\footnotetext{
${ }^{9}$ O retrato desativado, de Bonvicino. O retrato sem ação, sem efeitos, sem práxis, sem a possibilidade de assumir uma atitude perante o oásis. Um retrato coberto de palhas.
} 
as características é conservar o corpo, o corpomorto. Enquanto a taxidermia retira (todo o excesso de carne e de gordura) e preenche, cozinha e conserva, o $\mathrm{CsO}$ retira e goza, cozinha e degusta. Pois, para o $\mathrm{CsO}$, um corpo é tão somente

[...] um conjunto de válvulas, represas, comportas, taças ou vasos comunicantes: um nome próprio para cada um, povoamento do CsO, Metrópoles, que é preciso manejar com o chicote. O que povoa, o que passa e o que bloqueia? Um $\mathrm{CsO}$ é feito de tal maneira que ele só pode ser ocupado, povoado por intensidades. (DELEUZE; GUATTARI, 1996, p. 13)

O corpo taxidérmico é tão somente uma propaganda de sorrisos para a Colgate. A taxidermia transforma um corpo em vazio, para preenchê-lo de palha, seja lá com qual gosto e sentido; o CsO esvazia, esgota, para povoar com intensidades. Com potências. A taxidermia é um processo de retirada de tudo o que é inútil, feio, de todas as marcas e vestígios, de tudo o que é sujo de um corpo, para purificá-lo e conservá-lo em seu mais belo estado natural. ${ }^{12}$ Conservar o oásis, a fim de to sell mais sandálias. Fazer para si um $\mathrm{CsO}$ é retirar tudo que é natural, tudo o que faz sentido, retirar o conjunto de significâncias e subjetivações, sujar-se, sujeitar-se, marcar-se, tornar-se potência, retirar a morte, devolvendo-lhe a plena vida. Desertificação. O CsO, a política máxima da vida.

Novamente, a Taxidermia é o tributo ao corpo morto. Ela é cruel, mortífera, e carnívora. Moralmente carnívora. Ela glorifica a verdade para preservar o corpo, principalmente se compreendermos sentido como função,

\footnotetext{
${ }^{10}$ Ou silicone, no caso de uma modelo.

${ }^{11}$ Uma preocupação constante dos manuais de taxidermia consultados é para com as moscas. Conforme uma rápida rememoração da biologia do Ensino Médio, moscas e demais animais "sujos" são atraídos por matéria orgânica em decomposição. A taxidermia evita ao máximo o que é podre. $\mathrm{O}$ que se decompõe. Além disso, tudo o que é inútil, feio e sujo pode ser lido como tudo o que é vivo. O processo de decomposição é o processo de transformação, trans-metamorfose-ação do corpo orgânico ao corpo inorgânico. Sendo que o que os difere, segundo Deleuze, em A dobra, é apenas uma "diferença de vetor, indo o segundo em direção a massas cada vez maiores, [...] e indo o primeiro em direção a massas cada vez menores e polarizadas, nas quais se exerce uma maquinaria individuante, uma individuação interna" (DELEUZE, 1991, p. 21). O embalsamamento é o tratamento de cadáveres humanos com substâncias químicas a fim de evitar a decomposição; diferentemente da taxidermia que esvazia e preenche o corpo, o embalsamamento "apenas" banha o corpo, encharca-o de fluidos.

${ }^{12}$ Conservar em seu estado natural é conservar morto.
} 
ainda que, grosso modo, de um órgão. Taxidermia é o processo de permanecer limpo de sentido o corpo natural. O corpo existe, para a taxidermia, sem o sentido, vazio de qualquer sentido. O corpo para a taxidermia é somente verdade. Morto. Como Deus.

Por falar em Deus, Bonvicino, ainda em Página órfã, apresenta-nos um retrato de um Deus CsO. Por mais pecaminoso que seja falar em Deus com corpo, mais grave ainda é pensar em um corpo sem órgãos. Porém, é no corpo de Deus sem órgãos que o prazer invade o deserto: "Louco tesão/ que me invade de tesão/ minha língua desliza/ em seu sexo ereto// alisando sua virilha/ sem intérpretes/ seu pênis arrogante/ entra e sai// [...] esmagando o colo/ do meu útero/ onde neste canto agudo/ súbito Deus é útil.”

É através, atravessando, penetrando o deserto de um corpo sem órgãos definidos, nas barbatanas de um ânus, sem ínguas, que se chega a um canto, agudo, donde, subitamente, Deus deixa de ser verdade para ganhar sentido. Um tesão. De um réptil bruto sem intérpretes.

É na transformação do corpo uterino, orgânico que se atinge o corpo sem inibição, orgástico de um Deus útil. De um Deus com lugar no mundo. Isso somente é possível, pois o $\mathrm{CsO}$ de Deus é um processo de desertificação do próprio corpo, da vida que se inscreve, que é inscrita e proscrita ao corpo, é um processo de disseminação do sensível, dos vestígios, do que marca o corpo, é um processo de (dês)organização do corpo. Um tesão.

Cai os ni-ni palabra, ni concepto - de organismo e organização. O gozo, o júbilo desertificado só toca seu lugar no mundo por meio do CsO. O orgasmo, a orgazação atravessam o corpo de uma modelo, o corpo Deus, esvaziam os oásis Hollywood como répteis brutos, atingindo um canto agudo, um canto arestal.

Temos agora, a partir dessas considerações, uma divisão explícita dos corpos. Por um lado, o corpomorto da taxidermia é pleno de palha, vazio de vida, o corpo de uma modelo de Régis Bonvicino. Estanque. Arte-final, pronta. Por outro lado, o CsO é pleno de vida, vazio de palhas, de sentidos naturais, de preenchimentos artificiais. Não siliconado. Móvel, dinâmico, arte em processo. $\mathrm{O}$ corpo repleto de sentido natural é o corpo máquina, o corpo sobrevida; também não muito distante do corpo repleto de preenchimentos naturais é o corpo religioso. 
Portanto, o que ensaiamos aqui é uma apologia à política máxima da vida, uma política de esvaziamento do sentido natural dos corposmortos da taxidermia e dos corpos máquinas daqueles que apenas sobrevivem, ao léu, dentre a multidão. Tal política é a política de zero, a política de intensidades e partidas.

Deleuze e Guattari nos lembram que o $\mathrm{CsO}$ faz passar intensidades, potências, porque ele as produz e as espalha em um espaço, em um ponto de partida, é passagem, a intensidade $=0$. Nada a ser interpretado, nada estratificado, organizado, o CsO é a derrocada do organismo, do conjunto natural de significâncias e verdades, é um processo de partida das intensidades, de retomada da (des)naturalização do sentido natural. Antes da formação de estratos representativos, interpretativos, ${ }^{13}$ o $\mathrm{CsO}$ é pleno de potência de sentido, e vazio de sentido em ato, é movimento. O CsO é infâmia, é o que não pode ser dito, porque a ele só importa o que não tem nome. Não importa o olho, e seu sentido visão, pouco importa o ouvido e seu sentido, sua função, não importa se o corte da sensível pele ao redor do olho deve ser de 10, 15 ou 20 centímetros. Importa o apêndice do não sentido, importa o inominável. CsO não tem órgãos, não tem rosto - "e no rosto/ não há palavras/ morto a pauladas/ não tem conversa não" (BONVICINO, 2007, p. 23-24) Não tem nome, não tem conversa. Ao $\mathrm{CsO}$, o corte de 10,15 ou 20 centímetros é no próprio olho.

Eis então não suportar mais os olhos para ver, os pulmões para respirar. Substituir a anamnese pelo esquecimento, a interpretação pela experimentação, como propõem Deleuze e Guattari, é adotar o processo de (des)naturalização do sentido. É esquecer as verdades essenciais e latentes platônicas, ${ }^{15}$ é esquecer-se de interpretar os sentidos naturais. É experimentar toda a potencialidade do olho vazio, (des)naturalizado de sua verdade essencial, esquecendo-a:

\footnotetext{
${ }^{13}$ Ou antes da colocação de chumaços de algodão na boca e no ânus, antes do preenchimento de palha... Antes do estancar a arte ao passado...

${ }^{14}$ Fazemos referência ao filme O cão Andaluz, de Luis Buñel e Salvador Dalí, no qual aparece a já famigerada cena de um olho sendo cortado a navalha.

15 "No desvio de algum rincão do universo inundado pelo fogo de inumeráveis sistemas solares, houve uma vez um planeta no qual os animais inteligentes inventaram o conhecimento. Este foi o minuto mais soberbo e mais mentiroso da 'história universal', mas foi apenas um minuto." (NIETZSCHE, 2001b, p. 7). 
Ossos de borboleta sob um céu-eclipse - nas obras sem orgãos da coleção de panapaná ...

[...] somente graças à sua capacidade de esquecimento é que o homem pode chegar a imaginar que possui uma verdade no grau que nós queremos justamente indicar. Se ele recusa contentar-se com uma verdade na forma de tautologia, quer dizer, como cascas vazias, ele tomará eternamente ilusões por verdades. (NIETZSCHE, 2001b, p. 10)

Se ele recusa contentar-se com uma verdade na forma de ausência, quer dizer, como corpos sem órgãos, ele tomará eternamente o chumaço de algodão e um estoque infindável de palhas, a fim de preencher com ilusões as verdades, os desertos com oásis. E verdade aqui manobra-se enquanto moral; e o esquecimento enquanto possibilidade de esvaziamento, (des)naturalização da verdade.

Nietzsche, em uma das suas máximas e flechas - a de número 18 - do livro O crepúsculo dos ídolos: Ou como se filosofa com um martelo, afirma que "quem não sabe pôr sua vontade [potência] nas coisas lhes põe ao menos um sentido." (NIETZSCHE, 2006, p. 12) Quem não sabe pôr sua vontade nas coisas, amansa-lhes, recobre-as de palha, da boca ao ânus. Uma superfetação de verdades. Um acúmulo. Nunca dispêndio.

Raul Antelo ${ }^{16}$ nos lembra Mallarmé ao falar que sentido é um "lance de dados que nunca abolirá o acaso". O sentido é a eterna basculação entre sons/sens. Antelo nos conta que um artesão que molda um vaso a partir do vazio o faz vazio de sentido, somente significante. $\mathrm{O}$ vaso é não sentido. É somente quando o significante vaso entra em con-tato com outro significante que o sujeito ${ }^{17}$ realiza sentido.

Retornando a Nietzsche, vemos que as diferentes línguas, mesmo se comparadas, mostram que as palavras estão longe de alcançar a verdade. Se assim fosse, o número de línguas seria muito menor. "A 'coisa em si'," nos diz o filólogo alemão, "[como sendo precisamente a verdade pura e sem conseqüência], enquanto objeto para aquele que cria uma linguagem, permanece totalmente incompreensível" (NIETZSCHE, 2006, p. 11). A linguagem designa somente a relação homem/coisa, homem/mundo. A linguagem é o vasquejo de

\footnotetext{
${ }^{16}$ A partir de anotações feitas durante o curso Pós-estruturalismo e seus Desdobramentos, ministrado por Raul Antelo e Flávia Cera, no segundo semestre de 2008, para o curso de graduação em letras-português da UFSC.

${ }^{17}$ Aqui poderíamos fazer inferência ao sujeito singular-plural, de Jean-Luc Nancy. Porém, esse seria outro movimento de partida, outra intensidade. 
sentido entre homem/mundo. Para tanto, Nietzsche afirma que a linguagem adota as metáforas mais audaciosas: transpor uma excitação nervosa em uma imagem; e transpor a imagem em um som. Sens/sons.

Mais audaciosas ainda são as imagens criadas por Bonvicino. Ao vasquejar sons/sens, de ossos de borboleta, de borboflores, florbelhas, flormigas, borr, o poeta articula mundos e homens com seus desertos, não criando verdades, mas abrindo, atravessando novas possibilidades de sentido, convulsionando juízos de valor de verdades universais:

\begin{abstract}
Juízos, juízos de valor acerca da vida, contra ou a favor, nunca podem ser verdadeiros, afinal; eles têm valor apenas como sintomas, são considerados apenas enquanto sintomas - em si, tais juízos são bobagens. É preciso estender ao máximo as mãos e fazer a tentativa de apreender essa espantosa finesse [finura], a de que o valor da vida não pode ser estimado. Não por um vivente, pois ele é parte interessada, até mesmo objeto da disputa, e não juiz; e não por um morto, por um outro motivo. - Que um filósofo enxergue no valor da vida um problema é até mesmo uma objeção contra ele, uma interrogação quanto à sua sabedoria, uma não sabedoria. (NIETZSCHE, 2006, p. 18)
\end{abstract}

É preciso estender ao máximo as mãos, prolongar o corpo, é preciso criar para si um CsO para fazer a tentativa de apreender essa espantosa finesse - a finesse de compreender que é impossível valorar-se o sentido da vida, transformá-lo em verdade. É preciso negar o valor da vida e a morte, tornar-se um ainda-vivo. É preciso livrar-se da sintomática vida, para livrar-se das bobagens. É preciso não estar morto, e em um simultaneismo, não estar vivo. É estar acéfalo e assépalo, atravessando o deserto sob(re) pétalas (Me transformo - BONVICINO, 2007, p. 13-14). É estar hífen. Suspenso.

O filósofo - perdido no labirinto grego em linha reta - que faz o trabalho de julgar o valor da vida, por meio da moral, da lei, faz o trabalho do taxidermista, disseca, limpa, cozinha os podres para eliminar os maus sintomas. Já o filósofo que se estende ao máximo, projeta-se para o limite da vida, cria para si um $\mathrm{CsO}$, (des)naturalizando os valores naturais, convulsionando a verdade, a moral, o valor; deslocando a vida para o deserto.

Porém, se o CsO é a experimentação de (des)naturalização do sentido, de vasquejo do sens/sons, de um sentido natural, moral, de um sentido fabu- 
loso, ele é infâmia. Tal infame é a doença, de uma doença assintomática. Tal infame é o perigo, o risco de criar para si um $\mathrm{CsO}$, o perigo, o risco de tentar uma vida para além da vida. Uma questão de vida e de morte. Uma questão de experimentação.

A palavra experimentação tem como prefixo o ex-. Ex-, do latim, "movimento para fora, tirado de". Experimentação difere de experiência," pois aquela remete ao Perire, do italiano, "perecer, morrer, sucumbir". Experiência é o para fora, o que resta do que está morto. Experimentação é a ação de realização da experiência, é o processo de perecer, morrer, sucumbir, mas não enquanto corpo drogado de uma modelo, e muito menos a pauladas como mendigos. A experimentação proposta pelo CsO é o processo de morrer Deus, matar os órgãos, desfazer-se do organismo para melhor gozar a ausência do ni, para melhor gozar a experiência, ou ainda, para melhor gozar o orgasmo, com o que resta do que está morto.

Em outras palavras, manobrando outros mundos de sentidos, o $\mathrm{CsO}$ é a experimentação, para se chegar ao $\mathrm{CsO}$ é preciso experimentar. A experiência é o que se constitui após o experimento. A experimentação é a ação de transformar proposta por Nancy, em oposição à postura de interpretar-se, de fixação das verdades.

Afinal, se morta a vida, resta o corpo - conservado pela taxidermia, pela memória -, morto o organismo, resta o $\mathrm{CsO}$, ainda vivo. E se experiência é perigo, o CsO é o risco imanente de viver no limiar, de atravessar o deserto. Assim, o CsO configura-se limiar. Um passo além da própria vida, do próprio oásis, ao encontro de uma vida insuportável, desertificada.

É o atravessamento do sujeito por uma experiência do exterior - ao que Roland Barthes definiria como Punctum:

[...] o segundo elemento vem quebrar (ou escandir) o studium. Dessa vez, não sou eu que vou buscá-lo (como invisto com minha consciência soberana o campo do studium), é ele que parte da cena, como

\footnotetext{
${ }^{18}$ Recordamos que a palavra experimentação tem a mesma origem etimológica da palavra perigo. Experienc- remete, no dicionário Houaiss, a perig-, perigo.

${ }^{19}$ Cabe lembrar que durante esse percurso não estabelecemos referências às discussões de Benjamin acerca da experiência. As concepções adotadas aqui divergem das de Benjamin, inclusive na oposição por vivência. Nos desdobramentos deste trabalho, tentaremos abordar essa e outras questões que ainda perturbam o percurso aqui percorrido, como é o caso de práxis. 
uma flecha, e vem me transpassar. Em latim existe uma palavra para designar essa ferida, essa picada, essa marca feita por um instrumento pontudo; essa palavra me serviria em especial medida em que remete também a ideia de pontuação e em que as fotos de que falo são, de fato, como que pontuadas, às vezes até mesmo mosqueadas, com esses pontos sensíveis; essas marcas, essas feridas são precisamente pontos. A esse segundo elemento que vem contrariar o studium chamarei então punctum, pois punctum é também picada, pequeno buraco, pequena mancha, pequeno corte - e também lance de dados. O punctum de uma foto é esse acaso que, nela, me punge (mas também me mortifica, me fere). (BARTHES, 1984, p. 46)

O que mortifica-me, fere-me, punge-me, entrega-me à vida. O que mortifica-me, fere-me, punge-me são os répteis brutos, de um canto arestal, esmagando o colo de um útero - que pouco se vale órgão - tornando sentido a verdade. O que me mortifica prova-me a vida. Só morre, só se fere quem está vivo. E afinal, é a taxidermia um prolongamento da vida por meio da conservação do corpo, ou a exibição da morte. Ou o CsO é um prolongamento do corpo - vivo - por meio do vazio, do esvaziado. O CsO é o limiar da vida. Ou um para além da vida, uma vida insuportável, insustentável. Ou ainda, é possível viver em pleno deserto.

Para Deleuze e Guattari, o CsO é um plano de consistência, um limite ao qual nunca se chega, pois há sempre "um estrato atrás de outro estrato, um estrato engastado em outro estrato" (DELEUZE; GUATTARI, 1996, p. 21-22). ${ }^{20}$ O punctum barthesiano é justamente a experiência de atravessamento - experimentação -, de desfalecimento de todos os estratos, de todo o organismo. E aqui vale recordar que o $\mathrm{CsO}$ não é guerra ao corpo, e sim ao organismo, a essa organização orgânica dos órgãos. A guerra é a cruzada contra o juízo de Deus.

Porém, ao contrário de Deleuze e Guattari, o que aqui propomos é ser o $\mathrm{CsO}$ um limiar, uma fronteira tão dúbia e falenosa quanto as borboletas borboflores de Bonvicino. Se aceitarmos o $\mathrm{CsO}$ enquanto limite, entraríamos no paradoxo de impor ao deserto um fim - ou seja, transformá-lo-íamos em verdade. Contudo, se o pensarmos como limiar adotaríamos a atitude de compreender o $\mathrm{CsO}$ enquanto uma política máxima de vida, enquanto um mundo

\footnotetext{
${ }^{20}$ Porém, um estrato atrás de outro estrato, atrás de outro estrato não seria uma teoria de representação? 
de possibilidades de se viver em pleno deserto, ou de se viver de oásis a oásis, em constante travessia pelo deserto afora.

Ni palabra, ni concepto, o CsO é uma atitude. É o não conformar-se com o oásis. É o não limitar-se às verdades a nós impostas.

Agora, desfazer-se do organismo não é matar-se. A guerra do $\mathrm{CsO}$ também é contra a morte. ${ }^{21}$ A vontade é chegar ao limite, testar o limite - tocar o limiar. É abrir o corpo, não para intumescê-lo de palha e sentidos naturais, mas para abri-lo às "conexões que supõem todo um agenciamento, circuitos, conjunções, superposições e limiares, passagens e distribuições de intensidade [...]" (DELEUZE; GUATTARI, 1996, p. 22). O pior não é permanecer estratificado: assim se sobrevive. O pior é precipitar os estratos em uma alucinada e demente queda, em uma tentativa insuportável de aboli-los. É abrir sorrisos para a Colgate enquanto se entope nos bastidores. O CsO é processo, é movimento. Aos poucos, órgão por órgão, desmonta-se a estrutura organismo. É experimentar um órgão, degustá-lo, esgotá-lo, devolvê-lo à potência para então ressignificá-lo. E, então, com um novo sentido, voltar a (des)naturalizá-lo, voltar a degustá-lo, tornar a esquecê-lo. Ou, retomando a imagem que nos acompanhou até agora, atravessar o deserto, atingir um novo oásis e recuperar o fôlego a fim de continuar a travessia.

O prolongamento do corpo leva-nos a uma vida em contato, uma vida possível. Se o CsO é a experiência de (des)naturalização, é experimentação, ele se configura enquanto limiar vida-morte; ele se configura como ainda-vivo. Já o taxidermista age com suas palhas de lei e chumaços de moral, estancando a vida em suas muralhas de verdade, preservando-a das más influências, conservando-a longe, principalmente das ações do tempo, da decomposição... Não havendo muita distância entre o taxidermista e a religião ${ }^{22}$ que cultua 0 deus-pai-corpomorto.

Já a atitude de encarar o deserto enquanto processo é percebida desde Nietzsche, prolongando-se para aliviar-se de O mais pesado dos pesos:

\footnotetext{
${ }^{21}$ Para aprofundar as relações do CsO com a morte, ver a análise de tecido canceroso, que Deleuze e Guattari propõem no ensaio (DELEUZE; GUATTARI, 1996, p. 26).

${ }^{22}$ O CsO é, segundo Deleuze e Guattari, o campo de imanência do desejo, o plano de consistência própria do desejo. É o lugar no qual o desejo se configura como processo, sem referência, sem dependência de qualquer instância exterior, pois o desejo é oco, vazio, pleno de potência. Cada vez que um desejo é traído, é por que há ali um padre (DELEUZE; GUATTARI, 1996, p. 15).
} 
[...] e se um dia, ou uma noite, um demônio lhe aparecesse furtivamente em sua mais desolada solidão e dissesse: "Esta vida, como você a está vivendo e já viveu, você terá de viver mais uma vez e por incontáveis vezes; e nada haverá de novo nela, mas cada dor e cada prazer e cada suspiro e pensamento, e tudo o que inefavelmente grande e pequeno em sua vida, terão de lhe suceder novamente, tudo na mesma sequência e ordem - e assim também essa aranha e esse luar entre as árvores, e também esse instante e eu mesmo. A perene ampulheta do existir será sempre virada novamente - e você com ela, partícula de poeira!" - Você não se prostraria e rangeria os dentes e amaldiçoaria o demônio que assim falou? Ou você já experimentou um instante imenso, no qual lhe responderia: "Você é um deus e jamais ouvi coisa tão divina!" Se esse pensamento tomasse conta de você, tal como você é, ele o transformaria e o esmagaria talvez; a questão em tudo e em cada coisa, "Você quer isso mais uma vez e por incontáveis vezes?", pensaria sobre os seus atos como o maior dos pesos! Ou o quanto você teria de estar bem consigo mesmo e com a vida, para não desejar nada além dessa última, eterna confirmação e chancela? (NIETZSCHE, 2001a, p. 230)

\title{
4. De massas e dobras: A arte deserto e seus vestígios
}

\author{
Quantas vezes esfregou \\ os dedos nas unhas \\ o sol caindo atrás das paredes \\ quantas vezes revezou-se \\ consigo mesmo em silêncio \\ quantas vezes esteve \\ no justo oriente de qualquer \\ limo \\ quantas vezes quis \\ ser Rimbaud e traficou \\ aspirina \\ os dias passaram, severos, \\ como o vazio \\ hoje? ontem?, quantas vezes? \\ as grimpas não giraram \\ o amor era das palavras, entre
}


Ossos de borboleta sob um céu-eclipse - nas obras sem orgãos da coleção de panapaná ...

elas
fria estrela que irrompe

Régis Bonvicino

É isso que Leibniz explica em um texto extraordinário: um corpo flexível e elástico tem ainda partes coerentes que formam uma dobra, de modo que elas não se separam em partes de partes, mas dividemse até o infinito em dobras cada vez menores, dobras que sempre guardam certa coesão. Do mesmo modo, o labirinto do contínuo não é uma linha que se dissolveria em pontos independentes, como a areia fluida dissolve-se em grãos, mas é como um tecido ou folha de papel que se divide em dobras até o infinito ou que se decompõe em movimentos curtos, sendo cada um deles determinado pela circunvizinhança consistente ou conspirativa. [...] Sempre uma dobra na dobra, como uma caverna na caverna.

Em resumo, uma vez que dobrar não se opõe a desdobrar, trata-se de tender-distender, contrair-dilatar, comprimirexplodir (não condensar-rarefazer, que implicaria o vazio.

Gilles Deleuze

Quantas vezes esfregou os dedos entre as dobras da unha, quantas vezes revezou-se, desdobrou-se em silêncio, traficando aspirinas pelo ar. Severamente. Hoje? Ontem? As grimpas não giraram, pois o amor era das palavras. 
Entre elas, grãos de frias e feias e sujas e marcadas estrelas que irrompem no ar da devassidão de um universo-estrelado. Pleno de remorso em um céu-e(c) lipse (BONVICINO, 1999).

Em resumo, uma vez que dobrar não se opõe a desdobrar, trata-se de universo-estrela, céu-e(c)lipse, vida-morte, condensar-rarefazer-condensar. Trata-se de -. Hífen.

Quando Deleuze escreveu A dobra (Le pli), em 1988, estava em sintonia com artistas como de Kooning, Pollock, Lucio Fontana, John Cage, Gorski, os quais começavam - a partir de 1947 - a separar a arte da fenomenologia vigente até então, desconstruindo a ideia de que a obra é limite, é reprodução, identidade, imagem, interpretação. O conceito de dobra que Deleuze apresenta é o de que a arte é produção de presença - tão logo de ausência - com uma estrutura plissada, na qual o que importa é o quanto de ar a arte tem em si, retém consigo. O que importa é que vestígios a arte carrega. Antelo ainda nos recorda que Mil platôs, de Deleuze e Guattari, é uma introdução a uma vida não fascista. O platô, advindo da pastelaria, é uma massa folhada, uma sequência de dobras, nas quais mais importa o ar(te) retido (o vazio) entre as dobras do que a própria massa.

A diferenciação entre a massa podre e a massa folhada, Deleuze nos apresenta como sendo apenas vetorial. No processo de feitura da massa folhada, há um tempo determinado de espera para que a massa, em uma reação orgânica, putrefaça-se, para então amassar-se, dobrar-se e amassar-se, dobrar-se e amassar-se, inserindo nada mais que ar(te) entre uma dobra e outra. O processo de putrefação é o processo de vetorização do orgânico em inorgânico. ${ }^{23}$ É o processo de inanimar-se, ou melhor, (in)animar-se em um CsO. A massa podre é a massa sem vazio, é o corpo entulhado, esfarelado de palhas e algodões. A massa folhada é o corpo repleto de dobras, repleto de nada, é o corpo pleno de ar, arte esta que interrompe a reação orgânica, por que o natural não suporta o vazio.

A dobra é a possibilidade de (in)organizar, (in)operar um corpo. A dobra é a possibilidade de encher-se de ar(te) e criar para si um corpo sem órgãos, repleto de panapanás.

\footnotetext{
${ }^{23}$ Ou melhor, é inverter a ausência do ni do organismo transformado em orgasmo, o que nos dá a equação, organismo $-\mathbf{n i}=$ orgasmo. A putrefação da massa nas dobras da arte nos sugere mais uma equação, a transformação vetorial do ni em in + orgânico = inorgânico. A vetorização aqui referida pode ser comparada com o jogo da lógica e a (des)organização da gramática operadas por Bonvicino. 
Após divagar longamente entre teorias de corpos e homens, a pergunta que nos resta é donde fica a arte nessa balbúrdia toda... A arte, assim como o homem pós-humanista, é aqui entendida a partir de seus vestígios de arte. E a arte dos mundos dos sentidos ${ }^{24}$ é uma arte que não se configura, mesmo que pela exclusão bartlebyana do I prefer not to (MELVILLE, 2008). Entender o homem enquanto vestígio do homem é uma posição política - e da política máxima da vida, a política do $\mathrm{CsO}$ - de tornar suportável a insuportável natureza humano demasiado humano, sem cair na loucura, sem cair nos corpos esquizo, drogado, hipocondríaco etc. É a possível de não se contentar com os sorrisos para a Colgate, de querer ser mais, ir para além de.

A arte dos mundos dos sentidos é uma operação não de identificação, não de interpretação, e sim de disseminação de vestígios, de processos. É articular, estabelecer correspondências, transformar. O CsO criado pela arte não é uma forma ideal, e sim uma forma processual, é o nunca esgotar-se, o potencializar-se, mesmo que seja por meio da negatividade bartlebyana. A não verdade da arte apela para a sensibilidade, para o toque, para o que nos toca na arte. Para o toque que se desdobra, inserindo cada vez mais ar na arte.

É na meditação, na arte de pensar, de inflar-se com ar, liberando os chumaços de algodão de bocas e ânus, fazendo circular o ar, abrindo passagens, percorrendo processos, que a política máxima da vida se configura.

Criar para si um corpo sem órgãos é esvaziar-se de matéria orgânica e inflar-se de ar. Criar para si um corpo sem órgãos é uma política de vida. Uma política de meditar sobre a vida, fazendo-a valer a pena. A postura que aqui reconhecemos na arte é uma postura de compreender a vida enquanto passagem, e não assombrá-la enquanto passado, livrando-a do medo de ser apenas indivíduo, possibilitando ao sujeito singular imprimir suas marcas em um plural.

Possibilitando o (me) transformar-se em outro, não em mendigo, não em modelo. Em borboletas. Em um panapaná.

A política máxima da vida é a política do esvaziamento das diferenças entre corações, olhos, mentes, bolsos e cores na pele, é a possibilidade de engolir o algodão e (in)operar preconceitos - conceitos naturais. A política máxima da vida é da vida, para vida, e com vida. E os ares de sua graça e os

\footnotetext{
${ }^{24}$ E por arte dos mundos do sentido entendemos a arte que pode operar com o CsO, desertificar a verdade, desconstruir dogmas, ir a contrapelo da hegemonia. 
ares de sua arte são duros como ossos e leves como borboletas.

\section{REFERÊNCIAS}

ANTELO, Raul. Limiar. In: BONVICINO, Régis. Ossos de borboleta. São Paulo: 34, 1996, p. 143.

BARTHES, Roland. A câmara clara. Rio de Janeiro: Nova Fronteira, 1984.

BONVICINO, Régis. Ossos de borboleta. São Paulo: Ed. 34. 1996.

Remorso do cosmos: de ter vindo ao sol. São Paulo: Ateliê Editorial, 2003.

Página órfã. São Paulo: Martins Fontes, 2007.

Céu-eclipse. São Paulo: 34, 1999.

DELEUZE, Gilles. A dobra: Leibniz e o barroco. Campinas: Papirus, 1991.

; GUATTARI, Félix. Mil platôs. v. 3. Rio de Janeiro: 34, 1996.

;

Mil platôs. v. 5. São Paulo: 34, 1997.

HANSEN, João Adolfo. A palavra-carcaça de Bonvicino. In: Bonvicino, Régis. Página órfã. São Paulo: Ateliê Editorial, 2007, p.111.

MELVILLE, Herman. Bartleby, o escriturário. 2. ed. Porto Alegre: L\&PM, 2008.

NANCY, Jean-Luc. EI sentido del mundo. Buenos Aires: La Marca, 2003.

. Tres fragmentos sobre nihilismo y política. In: ESPOSITO, Roberto et al. (Orgs.). Nihilismo y política. Buenos Aires: Manantial, 2008.

El vestigio del arte. In:

. Las musas. Buenos Aires: Anurrortu, 2008.

Being singular-plural. Califórnia: Stanford University, 2000.

NIETZSCHE, Friedrich. Crepúsculo dos ídolos: Ou como se filosofa com um martelo. São Paulo: Companhia das Letras, 2006.

A gaia ciência. São Paulo: Companhia das Letras, 2001a.

Sobre a verdade e a mentira no sentido extramoral. Revista Comum, Rio de Janeiro, v. 6, n. 17. jul.-dez. 2001 b.

PERNIOLA, Mário. Enigmas: egípcio, barroco y neo-barroco en la sociedad y el arte. Múrcia: Cedart, 2006.

VÁZQUEZ, Adolfo Sánchez. Filosofia da práxis. 2.ed. Rio de Janeiro: Paz e Terra, 1977. 
Ossos de borboleta sob um céu-eclipse - nas obras sem orgãos da coleção de panapaná ...

Recebido para publicação em 09 de julho de 2009. Aceito para publicação em 29 de abril de 2010. 